\title{
Effect of body condition score on the allometric measurements and reproductive performance of garole $x$ malpura ewes under hot semi-arid environment
}

\begin{abstract}
Aim: A study was conducted with the primary objective to establish the influence of body condition scoring on the growth and reproductive performance of Garole $\mathrm{x}$ Malpura ewes.

Methods: The duration of the study was for five months involving 97 adult Garole $X$ Malpura (GM) ewes. The animals were allocated in three groups by body condition score $(2.5$ BCS; $\mathrm{n}=11, \mathrm{BCS} 3.0 ; \mathrm{n}=59$ and BCS $3.5 ; \mathrm{n}=27)$. All the animals were kept under semi-intensive management system by subjecting the animals to grazing during day time and housing them in the night. Apart from grazing, ewes were provided with concentrate mixture at the rate of $150 \mathrm{~g} /$ day/ewe. The ewes in estrus after $12 \mathrm{~h}$ of onset of estrus were hand mated twice at $12 \mathrm{~h}$ intervals with a ram of proven fertility in the morning and evening. The pregnancy was confirmed by real time B-mode transabdominal ultrasonography. The experiment was continued until lambing. Under the different BCS, the ewe's growth and reproductive parameters were assessed.

Results: BCS significantly $(\mathrm{P}<0.05)$ influenced body weight, heart girth, lambing \%, and birth weight of lambs. The highest $(\mathrm{P}<0.05)$ body weight was recorded in $3.5 \mathrm{BCS}$ group while the lowest $(\mathrm{P}<0.05)$ being in $2.5 \mathrm{BCS}$ group (Table 1). The highest $(\mathrm{P}<0.05)$ heart girth was recorded in 3.5BCS group while the lowest $(\mathrm{P}<0.05)$ being in 2.5 BCS group. The highest $(\mathrm{P}<0.05)$ lambing rate recorded in $3.0 \mathrm{BCS}$ group while the lowest $(\mathrm{P}<0.05)$ was in 2.5 BCS group. Further the highest $(\mathrm{P}<0.05)$ birth weight recorded being in $2.5 \mathrm{BCS}$ group.

Conclusion: Thus it can be concluded from the study that active management of Garole X Malpura sheep flock to maintain optimum BCS will help to ensure an economically viable production system.
\end{abstract}

Keywords: body condition score, body weight, garole $\times$ malpura sheep, growth, reproductive performance
Volume 2 Issue 6 - 2015

\author{
Veerasamy Sejian, ${ }^{1,2}$ Vijai Prakash Maurya, ${ }^{1,3}$ \\ Lawrence Leslie Leo Prince,' Davendra \\ Kumar,' Syed Mohammad Khrusheed Naqvi' \\ 'Central Sheep and Wool Research Institute, India \\ ${ }^{2}$ National Institute of Animal Nutrition and Physiology, India \\ ${ }^{3}$ Indian Veterinary Research Institute, India
}

\begin{abstract}
Correspondence: Veerasamy Sejian, Senior Scientist, Animal Physiology Division, National Institute of Animal Nutrition and Physiology, Adugodi, Bangalore-560030, India, Tel +91 974072 6|2|, Fax+91080 257| 1420, Email drsejian@gmail.com
\end{abstract}

Received: October 28, 2015 | Published: December 15, 2015

\section{Introduction}

The Garole is the only known prolific sheep breed in India and is a native of Sunderban, the swampy delta region of West Bengal. ${ }^{1}$ Malpura is a popular mutton-type breed of semi-arid tropical region of India. These sheep are known for their hardiness and adaptability to the local environment but prolificacy is low with ewes usually producing single lambs. Increasing prolificacy of the Malpura sheep has always been an important breeding goal in the semi-arid region of India. Hence the most prolific Garole sheep had been crossed with Malpura breed with more desirable characteristics to obtain a cross breed of higher productivity. Thus Garole x Malpura half-breds were evolved for increasing both prolificacy and adaptive capability of this breed.

In the arid and semi-arid region, rareness of feed, water and adverse climatic conditions lead to lower body condition score (BCS) and limiting sheep production. BCS is a subjective way to evaluate the status of a sheep flock and it acts as a potential indicator for sheep owners to increase production efficiency in their flocks. ${ }^{2}$ There is an optimum condition score for each ewe in the flock for each stage of the production cycle. Hence if one is considering optimizing the productivity from sheep industry, proper importance has to be given to ensure appropriate body condition for the ewes at different stages of production. Only optimum body condition ewes will be able to give better return in terms of reproductive efficiency.

Reproduction is a major and important component of the productive efficiency for a ewe-lamb system. Ewes must have adequate amount of body fat as an indicator of energy store to maintain their health, reproductive function and productive capacity. ${ }^{3}$ Body score is based on a subjective assessment of the fat level and muscle thickness on the backbone behind the last rib, according to a five-point scale described by Russel et al. ${ }^{4}$ A sheep flock consists of ewes of different sizes, body conditions and different levels of production and therefore they have varying nutritional needs. Although it is impossible to treat each ewes needs separately, many times it is beneficial to divide the flock into groups of ewes having similar needs. To improve body condition score of ewes by one score requires good grazing for 6 to 10 weeks. Overconditioned ewes can have reduced reproductive performance and therefore overfat ewes should be separated off and grazed optimally before the breeding season. Body condition score in sheep can be useful tool for assessing the flocks at mating time. ${ }^{5}$ The ewes with low body fat reserves have fewer large ovarian follicles due to which 
less number of follicles reach to the final stage of development and ovulate with greater possibility of reproductive failure and reduction in the production level. ${ }^{6}$ The ewes with appropriate body condition score (BCS) throughout gestation and after lambing, have higher productivity than ewes of poor BCS. ${ }^{4}$

To optimize the productivity of sheep, it is therefore, essential to have a simple and reliable indicator to assess nutrition level of ewes and decide when and how to supplement the flock. ${ }^{7}$ The BCS method is a simple, non-invasive, time saving and effective technique to rank ewes according to their body reserve. Although a large number of literature on the effect of BCS on reproductive and productive efficiency of exotic sheep is available, very little information are available in the Indian context. With these views, the present study was conducted with the primary objective to establish the influence of body condition score on the growth and reproductive performance of Garole X Malpura ewes.

\section{Materials and methods}

\section{Site of study and climate}

The experiment was carried out at the Central Sheep and Wool Research Institute farm, which is located in the semi-arid region of the country at longitude $75^{\circ} 28^{\prime} \mathrm{E}$ and the latitude of $26^{\circ} 26^{\prime} \mathrm{N}$ and at altitude of $320 \mathrm{~m}$ above mean sea level. The mean relative humidity ranged between from 20 to $85 \%$. The maximum and minimum ambient temperature ranged between 6 to $46^{\circ} \mathrm{C}$. The annual rainfall in this area ranges from 200 to $400 \mathrm{~mm}$ with an erratic distribution throughout the year. The study was conducted between March to July, 2009. During the study period the mean environmental temperature and relative humidity ranged between $22.8-38.2^{\circ} \mathrm{C}$ and $35-52$ percent, respectively.

\section{Animals}

The Garole sheep was procured from the native tract in 1997 and adapted at Sheep Breeding Farm, CSWRI Avikanagar. A crossbreeding programme was started with the aim to introduce the $F e c B B$ allele from dwarf Garole into Malpura sheep for enhancing the prolificacy. Garole rams were crossed randomly with Malpura ewes to produce GM halfbreds that supposed to segregate the FecBBallele of GM progenies (F1). Thereafter, inter-se mating was performed in the established flock of GM sheep to produce F2 and F2 onwards generations. All individuals were ear tagged and maintained under standard farm management practices. A total of 97 Garole X Malpura ewes were selected for the study. Sheep were grazed daily for 8-10h on native Cenchrusciliaris pastures interspersed with natural grasses, shrubs and fobs (Achyranthes aspera, Commelina forskalaei, Eleusine aegypticae and Sorghum helepense). The animals were housed in well-ventilated sheds made up of asbestos roofing at the height $2.4 \mathrm{~m}$ and open from side and maintained under proper hygienic conditions. The animals had Ad libitum access to good quality drinking water. Prophylactic measures against sheep diseases like sheep pox, peste des petits ruminants, enterotoxaemia, endo and ectoparasitic infestations were carried out as prescribed by the health calendar of the institute to ensure that the animals were in healthy condition throughout the study.

\section{Experimental design}

The study was conducted for five months in 97 adult Garole $X$ Malpura (GM) ewes. The animals were segregated based on body condition scoring (2.5 BCS; $\mathrm{n}=11, \mathrm{BCS} 3.0 ; \mathrm{n}=59$ and $\mathrm{BCS} 3.5 ; \mathrm{n}=27$ ) into three groups, respectively. All the animals were kept under semi- intensive management system by subjecting the animals to grazing during day time and housing them in the night. Apart from grazing, ewes were provided with concentrate mixture at the rate of $150 \mathrm{~g} /$ day $/$ ewe (barley, $650 \mathrm{~g} / \mathrm{kg}$, groundnut cake, $320 \mathrm{~g} / \mathrm{kg}$, minerals $30 \mathrm{~g} /$ $\mathrm{kg}$ including $10 \mathrm{~g} / \mathrm{kg} \mathrm{NaCl}$, with crude protein $=180 \mathrm{~g} / \mathrm{kg}$ and total digestible nutrients $=650 \mathrm{~g} / \mathrm{kg}$ ). Estrus in each ewe was detected by parading aproned rams of proven vigour at every $6 \mathrm{~h}$ intervals for $30 \mathrm{~min}$ at early morning (6:00), noon (12:00), evening (18:00) and midnight (24:00). The ewes in estrus after $12 \mathrm{~h}$ of onset of estrus were hand mated twice at $12 \mathrm{~h}$ intervals with a ram of proven fertility in the morning and evening. The pregnancy was confirmed by real time B-mode transabdominal ultrasonography (Model SA-600V; MEDISON, Seoul, Korea) at 50 days of gestation. The experiment was continued until lambing. Under the different BCS, the ewe's growth and reproductive parameters were assessed.

\section{Body condition scoring}

The BCS method described by Russel et al., ${ }^{4}$ was used condition score the experimental animals to give a final score in three categories viz., 2.5, 3.0 and 3.5 points. BCS was assessed by careful palpation of the spinous and transverse process in the loin area, immediately behind the last rib. The BCS was assessed at monthly interval to ensure that they were in respective BCS as per the experiment.

\section{Parameters studied}

The allometric measurements studied were heart girth (HG), pin shoulder length (PSL), height at withers $(\mathrm{H})$ and body weight (BW) of ewes. The reproductive parameters included in the study were lambing rate, litter size, twinning percentage and birth weight of lambs.

\section{Data analysis}

The least squares procedures (Harvey, 1990) were used to analyze the data on body weight and other allometric measurements of Garole $\mathrm{X}$ Malpura sheep. The data on all the parameters included in the study were classified according to three different BCS. Significant differences between means were detected using Duncan's multiple range test. The data on litter size was analyzed by analysis of variance (ANOVA) using general linear model procedure (GLM) of SPSS 16.0 for Windows.

\section{Results}

\section{Effect of BCS on the allometric measurements}

The BCS had significant $(\mathrm{P}<0.05)$ influence on the body weight among the different groups (Table 2$)$. The highest $(\mathrm{P}<0.05)$ body weight recorded being in $3.5 \mathrm{BCS}$ group while the lowest $(\mathrm{P}<0.05)$ being in $2.5 \mathrm{BCS}$ group. The highest $(\mathrm{P}<0.05)$ heart girth recorded being in 3.5 BCS group while the lowest $(\mathrm{P}<0.05)$ being in $2.5 \mathrm{BCS}$ group (Table 1). However, pin-shoulder length and height at wither did not differ between the groups.

\section{Effect of BCS on the reproductive performance of ga- role $X$ malpura ewes}

The BCS had significant $(\mathrm{P}<0.05)$ influence on the lambing rate. The highest $(\mathrm{P}<0.05)$ lambing rate recoded was in 3.0BCS group while lowest $(\mathrm{P}<0.05)$ was in $2.5 \mathrm{BCS}$ group (Table 2$)$. However, litter size and twinning percentage did not differ between the groups. Further, birth weight of lambs showed significant $(\mathrm{P}<0.05)$ variation between the groups. The highest $(\mathrm{P}<0.05)$ birth weight recorded being in $2.5 \mathrm{BCS}$ group Table 2. However, birth weight of lambs did not differ between 3.0 and 3.5BCS groups. 
Table I Effect of BCS on the allometric measurements of Garole X Malpura ewes

\begin{tabular}{llllll}
\hline BCS & $\mathbf{n}$ & Body weight(Kg) & Heart girth(cm) & Pin-shoulder length(cm) & Height at wither(cm) \\
\hline 2.5 & II & $22.00 \pm 0.59^{\mathrm{c}}$ & $61.46 \pm 1.23^{\mathrm{b}}$ & $53.27 \pm 1.15^{\mathrm{a}}$ & $52.73 \pm 0.99^{\mathrm{a}}$ \\
3 & 59 & $24.55 \pm 0.26^{\mathrm{b}}$ & $64.88 \pm 0.53^{\mathrm{a}}$ & $53.75 \pm 0.49^{\mathrm{a}}$ & $53.70 \pm 0.43^{\mathrm{a}}$ \\
3.5 & 27 & $26.63 \pm 0.38^{\mathrm{a}}$ & $64.52 \pm 0.79^{\mathrm{a}}$ & $53.00 \pm 0.73^{\mathrm{a}}$ & $52.48 \pm 0.63^{\mathrm{a}}$
\end{tabular}

Values are the Mean and SEM

Values were recorded just before mating

Values in respective column having different superscript differ significantly@ P $\leq 0.05$

Table 2 Effect of BCS on the reproductive performance of Garole X Malpura ewes

\begin{tabular}{llllll}
\hline BCS & $\mathbf{n}$ & Lambing rate(\%) & Litter size(no.) & Twinning(\%) & Birth weight of lambs(Kg) \\
\hline 2.5 & 11 & $72.72(8)^{\mathrm{b}}$ & $1.82 \pm 0.21^{\mathrm{a}}$ & $63.64(7)^{\mathrm{a}}$ & $3.08 \pm 0.29^{\mathrm{b}}$ \\
3 & 59 & $88.13(52)^{\mathrm{a}}$ & $1.70 \pm 0.09^{\mathrm{a}}$ & $55.93(33)^{\mathrm{a}}$ & $3.12 \pm 0.12^{\mathrm{b}}$ \\
3.5 & 27 & $85.55(23)^{\mathrm{a}}$ & $1.74 \pm 0.14^{\mathrm{a}}$ & $62.96(17)^{\mathrm{a}}$ & $3.58 \pm 0.18^{\mathrm{a}}$ \\
\hline
\end{tabular}

Values are the Mean and SEM

Values were recorded just before mating

Values in parenthesis indicate no. of ewes out of total in respective group

Values in respective column having different superscript differ significantly@ P $\leq 0.05$

\section{Discussion}

Nutrition has an important impact on the reproductive performance in sheep, but the magnitude of nutritional effect on reproduction can vary with season. ${ }^{8}$ Nutritional status has also been correlated with embryo survival in ewe and marked as key factor influencing efficiency in animal reproduction technology. ${ }^{9}$ The body condition of ewes drastically affects the manifestation of sexual behaviour. Inadequate nutrition or body condition has been associated with delayed onset of the breeding season, decreased pregnancy rate, low birth weight of lambs. ${ }^{10}$

The body weight recorded in 3.5BCS was significantly higher than the lower BCS groups. The significant changes in the body weight of the different BCS groups indicate the precision of the condition scoring methodology adopted in this study. This will act as a clue in future strategy to meet the exact demands of nutrition for the ewes according to different production stages. Further, the findings of the present study revealed that $2.5 \mathrm{BCS}$ ewes had low heart girth and low body weight as compared to ewes having more BCS. This shows a strong positive correlation between BCS and allometric measurements. Nsoso et al. ${ }^{11}$ also reported a positive correlation of BCS with heart girth of ewes.

The present study revealed the significant influence of BCS on lambing rate. The highest lambing rate recorded was in 3.0 and 3.5BCS groups with no significance between these two groups. Similarly, Hatcher ${ }^{12}$ had reported maintaining Merino ewes at 3.03.5BCS during pregnancy ensured higher lambing rates indicating positive correlations of BCS with lambing rate. This indicates that the presence of an optimum BCS of ewes, especially as a sub-maximal feed intake, additionally saves costs of supplementary feeding and reduces wastes. ${ }^{13}$ Although there was significant effect of BCS on lambing rate but there was no significant effect on litter size and this was in agreement to the findings of Thomas et al., ${ }^{14}$ Thomas et al., ${ }^{14}$ found that mating ewes with BCS of 3.2 vs 2.9 resulted in a greater number of ovulations in higher BCS ewes but with little difference in the litter size. Further, Ptaszynska ${ }^{15}$ observed that in general, ewes respond optimally to flushing when in medium BCS rather than when exclusively thin or fat. BCS of ewes had significant influence on birth weight of lambs. The ewes of $2.5 \mathrm{BCS}$ had given birth to lambs of least average birth weight than by higher BCS ewes. This could be due to improper nutrition of lower BCS ewes during final stage of gestation. Al-Sabbagh et al. ${ }^{16}$ compared ewes with BCS (2.5 and 3.5), similar to those in our experiment and noted that ewes with the higher BCS, produced lambs with higher birth weight. Poor or limited nutrition during mid or late gestation has been implicated with low birth weights in some studies. ${ }^{17,18}$ This indicates that the ewes kept under the conditions of a hot, semi-arid environment should be maintained at moderate (3.0-3.5)BCS both at the mating stage and at the lambing stage to ensure an optimum return from these animals, rather than supplementing to increase the BCS to an even higher level. ${ }^{13}$

\section{Conclusion}

BCS had significantly influenced body weight, lambing rate and birth weight of lambs indicating BCS is an effective nutritional management tool for deciding the optimum nutrient requirement of sheep from economy point of view. Further, the ewes having a BCS of 3.0 performed better than lower and higher BCS ewes for most parameters studied. Thus it can be concluded that active management of Garole X Malpura sheep flock to maintain optimum BCS will help ensure an economically viable production system.

\section{Acknowledgements}

The authors are more grateful to the Director of the Institute for providing the research facilities and to Mr. K.C. Sharma for his technical help during the experiment.

\section{Conflict of interest}

Author declares that there is no conflict of interest. 


\section{References}

1. Kumar S, Mishra AK, Kolte AP, et al. Effects of the Booroola $(F e c B)$ genotypes on growth performance, ewe's productivity efficiency and litter size in Garole×Malpura sheep. Anim Reprod Sci. 2008;105(3-4):319-331.

2. Lowman BG, Scott NA, Sommerville SH. Condition scoring of cattle. Edinburgh: Bull No. 6. East of Scotland Coll. of Agriculture. 1976

3. Atti N, Theriez M, Abdennebi L. Relationship between ewe body condition at mating and reproductive performance in the fat-tailed Barbarine breed. Animal Research. 2001;50:135-144.

4. Russel AJF, Doney JM, Gunn RG. Subjective assessment of body fat in live sheep. J Agric Sci. 1969;72(3):451-454.

5. Gordon IR. Controlled Reproduction in Sheep and Goats. Oxford: CAB International; 1997

6. Michels H, Docuypere E, Onagbesan O. Litter size, ovulation rate and prenatal survival in relation to ewe body weight: Genetics review. Small Rumin Res. 2000;38(3):199-209.

7. Maurya VP, Sejian V, Kumar D, et al. Effect of induced body condition score differences on sexual behavior, scrotal measurements, semen attributes, and endocrine responses in Malpura rams under hot semiarid environment. J Anim Physiol Anim Nutri. 2010;94(6):e308-e317.

8. Naqvi SMK, Sejian V, Karim SA. Effect of feed flushing during summer season on growth, reproductive performance and blood metabolites in Malpura ewes under semi-arid tropical environment. Trop Anim Health Prod. 2013;45(1):143-148.

9. Webb R, Garnsworthy PC, Gong JG, et al. Control of follicular growth local interactions and nutritional influences. J Anim Sci. 2004;82E Suppl:E63-E74.
10. Maurya VP, Naqvi SMK, Mittal JP. Effect of dietary energy level on physiological responses and reproductive performance in Malpura sheep in hot semi-arid region of India. Small Rumin Res. 2004;55(13):117-122

11. Nsoso SJ, Aganga AA, Moganetsi BP, et al. Body weight, body condition score and heart girth in indigenous Tswana goat duting the dry and wet season in south Botswana. Livest Res Rural Dev. 2003;15(4):1-8.

12. Hatcher S. Ewe nutrition during late pregnancy-vital for ewe and lamb survival. Maximising the genetic potential of your flock. New South Wales: Newsletter; 2007.

13. Sejian V, Maurya VP, Naqvi SMK, et al. Effect of induced body condition score differences on physiological response, productive and reproductive performance of Malpura ewes kept in a hot, semi-arid environment. J Anim Physiol Anim Nutr. 2010;94(2):154-161.

14. Thomas DL, Thomford PJ, Crickman JG, et al. Effects of plane of nutrition and phenobarbital during the pre-mating period on reproduction in ewes fed differentially during the summer and mated in the fall. $J$ Anim Sci. 1987;64(4):1144-1152.

15. Ptaszynska M. Ovine reproduction. Compendium of animal reproduction. 6th Revised ed. Netherlands: Intervet International; 2001. p. 125-147.

16. Al-Sabbagh TA, Swanson LV, Thompson JM. The effect of ewe body condition at lambing on colostral immunoglobulin $\mathrm{G}$ concentration and lamb performance. J Anim Sci. 1995;73(10):2860-2864.

17. Russel AJF, Foot JZ, White IR, et al. The effect of weight at mating and of nutrition during mid-pregnancy on the birth weight of lambs from primiparous ewes. J Agric Sci. 1981;97(3):723-729.

18. Thomas VM, Mc Inerney MJ, Kott RW. Influence of body condition and lasalocid during late gestation on blood metabolites, lamb birth weight and colostrum composition and production in Finn-cross ewes. J Anim Sci. 1988;66(3):783-789. 